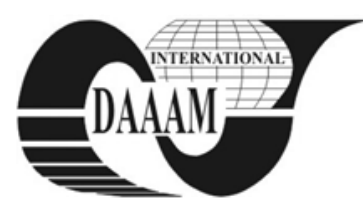

\title{
THE IMPACT OF EXTERNALIZATION OF MULTINATIONAL CORPORATIONS ON THE OPERATION OF INDUSTRIAL SMES
}

\author{
BOZIKOVA, L[ucia]; HRDINOVA, G[abriela]; KORTYS, M[arian] \& SAKAL, P[eter]
}

\begin{abstract}
The article deals with the behavioral tendencies of governments in the global environments. The first part points at assessing activity of foreign investors in the host country which is mentioned in the first part. The second part of the article analyzes the impact on the economy of engineering company that tries to compete with multinational organizations and highlights the way the CSR as a source of competitive advantage. The third parts give you an idea about the role of the host government which creates conditions for the arrival of foreign investors and suggests a strategy to strengthen the competitive advantage analysis engineering company.
\end{abstract}

Key words: responsible business, sustainable development, multinational corporations

\section{INTRODUCTION}

The huge transnational corporation, foreign investors, owners of the company which gross domestic product is higher than GDP some country of the world, peoples which are owners more than half of the world wealth, boast concept of corporate social responsibility. We are talking about concept, which is accepted by company voluntarily, and about the same concept which has become only marketing tools for peoples which try to veil facts about their devastating activities in the world. Example of this Pharisees behavior is company which is famous in Slovak republic like company finding young singers but on the other hand in another country is this company famous like distributor toxic waste and like the biggest purchaser of community water sources causing water shortages. Can it be a multinational organization really proud of the concept of corporate social responsibility? In times of globalization, in which we are the leaders of countries try to attracting these foreign investors into their territory in search of profit and development. Whether the activities of corporations in the host country actually "hand in hand" with sustainable development are trying to raise in the next chapter.

\section{SUSTAINABLE DEVELOPMENT VERSUS MULTINATIONAL CORPORATIONS}

It's a rule that state which tried to attract foreign investor into their territory must give the conditions for them which can be only dream for small and middle size companies on Slovak republic. Contributions to the newly created jobs, tax indulgences, and other financial subsidies. Resources which are returned for small and medium size company, traders, other working people, and all tax payers who spend funds for the entry of foreign investors in their home country are only promises. They are following:

- support the development of underdeveloped regions. But our leaders forget the fact that investors have a tendency to come in the regions where the necessary infrastructure is built. So, they are concentrated in developed regions and the less developed decline continues,
- infrastructure development. The host country must finance to build new infrastructure or to adapt it to needs of the foreign companies if it is necessary,

- the inflow of new technologies. There is no evidence that multinational corporations promote technological and economic development in the host country. Also very important is the fact that countries such as Slovakia in order to attract foreign investors undertake to contribute to research in his favor. The paradox is that no foreign investors, but the host country - the tax payers' Slovak republic contribute to science and research for foreign investors,

- create new jobs. Foreign investors create new jobs in the host country is questionable whether the number of new created jobs is the same like the number of work places which has lost in the case of inability to competitive from SME $s$ towards to favored state-supported enterprises. The second fact is a reality, that finance for create a new work place are offered to foreign investor. E.g. by the year 2010 the value of cost for newly created jobs in SR is around $30000 €$.

Other incentives for foreign investors, we include cheap labor or immediate access to raw materials and natural resources, tax - administration incentives provided by the government, for example, accelerated procedures for the transfer of property, benevolent advisement action of companies on the environment or protection.

Companies show us on their internet portals as they are protectors of environment that they are fighting for human rights and contributing to development of society despite the fact that the conditions for entry to the host territory in breach of the concept on which the report, and contrary to sustainable development (Hunter, 2003).

\subsection{Way socially responsible business to sustainable} competitive advantage for sustainable development

Small and medium sized enterprises in their home country are trying to match competitors from abroad by reducing production costs by reducing the value added, resulting in a reduction of profits and quality statements. Based on the analysis that we conducted in the engineering enterprise that ranks among the group of medium-sized businesses can do the following assessment. Revenues from the analyzed company has gone down to half in last years and it is not caused only by financial crisis, it is caused by new competition, which came in market. What has an impact on wages in the enterprise, workers decline, lack of funding to develop research activities in the enterprise.

Similarly, we can also talk about the negative impact on employment in the region in which the enterprise operates and increasing ineffectuality demand for the products of enterprise. Reducing costs is not the way, how businesses can be offset by foreign investors which part of their costs transferred to taxpayers in the host country. Right way is new strategy of fight which is oriented on corporate social responsibility and sustainable development. This strategy brings prosperity, and it 
is not only for company but for wider region in which the company operates.

\subsection{Idea the role of government host country, which support the arrival foreign investor in countries territory}

The most important aspect in the implementation of corporate SZ is the controllability.

The first idea of the state role is to provide controllability information, which are publicated by corporation with help stakeholders. Assess their relevance, whether the actual information on the implementation of CSR in Slovakia, or exist only on paper. When we are talking about CSR corporation, we mean a concept that should be done by every foreign investor, who wants to make a business in the host country. So the government's role should be:

- assecuration under the law consequential conduct program of corporate social responsibility company / multinational corporations affecting in the host country by foreign investor,

- control over implementation of CSR.

It the way how to avoid the deceptive manipulation of public opinion and inquiries undeserved competitive advantage over the other companies (Klinec et al., 2009). The government released considerable funds to support science and research for foreign investors, but not a rule that the results scientific and technological development, which is supported in the host territory came in to host country. As has been said in the previous section, there is no evidence that foreign investors support research and science in the host country. Another proposal for behavior of government is assecuration the enforcement of the scientific and technological development on the host country by corporations. It is necessary to ensure transparency of corporations and their control. Avoid situation when the company has a ascendance over the state and dictate of his own preferred conditions. The state should be fair to company with tradition in states the same as to foreign investors . The state must support them as well as supports large multinational corporations. Because only these companies can support their development and the development of the whole region and then the whole country. Who knows better, and it depends on what the region needs as a person who lives there, has family there and makes a bussiness here for a long time.

2.3 Proposal for a strategy to strengthen the bargaining position of small and medium - sized enterprises in competition with foreign corporations

We live in the world in which we follow the rules of the major players. The players who control the political world (Korten, 2001), affecting peoples opinion through the media which they are owned (Verick, 2009) and players who destroy environment (Zelený, 2001) exploitation of cheap, and child labor . It is possible that after completion of their business in the host country its remains only a huge ecological debt, which must be paid, and profit falls only for some "chosen". You could say that, even after times of crisis, the world had not take a lesson. The government support companies, which have a lot of sources and money. Companies externalizes their cost. Externalization is not a way to prosperity whole society. Our proposal to contribute to class balance in the world and to sustainable development is to focus on prosperity for small and medium-sized enterprises.

Our proposals to strengthen the position of SMEs in the era of globalization are the following:

- $\quad$ training sales professionals in these businesses- market is saturated with products that are easily interchangeable. So the customer can afford to dictate terms of sale. This kind of seals faces to so-called business from "grace", facility which are not for company the best. This kind of sale leads to so-called business from "grace", which are not for company the best. Seller - professional is a solution. Seller professional speaks with costumer as with peer, he don't let the costumer dictate the conditions and he know get the costumer where he needs it,

- $\quad$ implementation of CSR principles into every business activity - we suggest to use P-D-C-A Deming cycle in the form P-D-C-I , where I means improvement (Zelený, 2001),

- the suggestion to mutual co-operation between company and university - company according to this step would obtain a new and not prejudiced view of solving problem in company and new educated employee,

- $\quad$ the set up model EFQM into company activities - the model EFQM belongs to the most revised model of development management. Criterion the model is used like a inspiration of internal development and a evaluation in company. The set up model EFQM is the way how to reach continual sustainable rarity. The model is based on nine criterion's. Five of them make a presumptions and the rest is a result. The presumptions says what company makes and the result says what company reaches. There are between them a mutual link that result is created of presumptions which is constantly getting better via feedback of result. The model is based on presumptions of excellent result with respect to performance of customer, employee.

\section{CONCLUSION}

This paper refers to the importance of corporate social responsibility and sustainable development. Document say about the importance of support small and middle size company and about the needs of control the concept CSR in host country. The article gives answers to questions, how can small and medium sized company fight against big corporations. The article gives a way how to be competitiveness. It is a instruction for small and medium sized industry company.

\section{ACKNOWLEDGEMENTS}

This paper was supported by the Slovak Research and Development Agency under the contract No. LPP-0384-09: "Concept HCS model 3E vs. Concept Corporate Social Responsibility (CSR)." The paper is also a part of submitted KEGA project No. 037STU-4/2012 "Implementation of the subject "Corporate Social Responsibility Entrepreneurship" into the study programe Industrial management in the second degree at MTF STU Trnava".

\section{REFERENCES}

Hunter, R. (2003), Myths about foreign direct investment, Available from: http://www.euractiv.sk/ekonomika-aeuro/analyza/myty-o-priamych-zahranicnych-investiciach, Accessed : 2001- 05-27

Hvižd’ala, K. (2005), how to think media, Dokořán, ISBN-807363-047-8, Praha

Klinec, I., Pauhofová, I., Staněk, P. (2009) The new global environment, change the parameters of a redistribution of wealth in the 21st century, Institute of Economic Research SAV, ISNN-1337-5598, Bratislava

Korten, D.(2001) When corporations rule the world, Mikulás Hučko. ISBN-80-9686-03-0-5, Košice

Zelený,J. (2001) Environmental policy and management organizations. Faculty of Natural Sciences UMB, ISBN978- 80- 8083- 972- 7, Banská Bystrica

Verick, M. A. (2009) Media monopoly, EarthSave, ISBN-97880-86916-09-5, Praha

***(2011)http://ondrias.sk/index.php/knihy.htmltask=mdownlo ad\&id=12 - Books, Accessed on: 2011-05-27

***(2011)www.scss.sk - Slovak Centre for Strategic Studies, Accessed on: 2011-05-27 